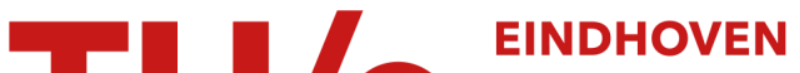 \\ UNIVERSITY OF \\ TECHNOLOGY
}

\section{The separation of herbicides by micellar electrokinetic capillary chromatography}

Citation for published version (APA):

Wu, Q., Claessens, H. A., \& Cramers, C. A. (1992). The separation of herbicides by micellar electrokinetic capillary chromatography. Chromatographia, 34(1-2), 25-30. https://doi.org/10.1007/BF02290454

DOI:

10.1007/BF02290454

Document status and date:

Published: 01/01/1992

Document Version:

Publisher's PDF, also known as Version of Record (includes final page, issue and volume numbers)

Please check the document version of this publication:

- A submitted manuscript is the version of the article upon submission and before peer-review. There can be important differences between the submitted version and the official published version of record. People interested in the research are advised to contact the author for the final version of the publication, or visit the $\mathrm{DOI}$ to the publisher's website.

- The final author version and the galley proof are versions of the publication after peer review.

- The final published version features the final layout of the paper including the volume, issue and page numbers.

Link to publication

\section{General rights}

Copyright and moral rights for the publications made accessible in the public portal are retained by the authors and/or other copyright owners and it is a condition of accessing publications that users recognise and abide by the legal requirements associated with these rights.

- Users may download and print one copy of any publication from the public portal for the purpose of private study or research.

- You may not further distribute the material or use it for any profit-making activity or commercial gain

- You may freely distribute the URL identifying the publication in the public portal.

If the publication is distributed under the terms of Article $25 \mathrm{fa}$ of the Dutch Copyright Act, indicated by the "Taverne" license above, please follow below link for the End User Agreement:

www.tue.nl/taverne

Take down policy

If you believe that this document breaches copyright please contact us at:

openaccess@tue.nl

providing details and we will investigate your claim. 


\title{
The Separation of Herbicides by Micellar Electrokinetic Capillary Chromatography
}

\author{
Q. Wu / H. A. Claessens*/C. A. Cramers \\ Eindhoven University of Technology, Laboratory of Instrumental Analysis, P.O. Box 513, 5600 MB Eindhoven, \\ The Netherlands
}

\author{
Key Words \\ Electrokinetic capillary chromatography \\ Micellar agents \\ Chlorophenoxy acids \\ Herbicides
}

\begin{abstract}
Summary
A method for the separation of a number of herbicides consisting of chlorophenoxy acids by micellar electrokinotic capillary chromatography (MECC) was developed. Sodium dodecyl sulphate (SDS), Brij 35, cetyltrimethylammonium bromide (CTAB) and methanol were introduced into the buffers to investigate their effects on the separation of the herbicides. SDS combined with Brij 35 as the micellar agent was found to provide the best overall separation of these components.
\end{abstract}

\section{Introduction}

The widespread use of chlorinated phenoxy acid herbicides has led to an increased pollution of soil, water and food by their residues and their phenolic metabolites. Their high toxicity to human and aquatic organisms [1] makes the development of sensitive methods for the analysis of compounds of this class essential.

A number of methods, particularly spectrophotometric $[2,3]$, differential pulse polarographic [4] and gas chromatographic [5-18], have been reported for the analysis of dericides. A strong disadvantage of GC methods is that befivatization of the target compounds is necessary and the final measurements. This is time consuming and may introduce errors in the analytical procedure.

High performance liquid chromatography (HPLC) and HPLC combined with mass spectrometry (LC-MS) have With been used to determine these compounds [19-28]. Separthese techniques no derivatization prior to the LC MS ation is needed. Moreover the coupling of LC with MS can provide both specificity and speed of analysis when applied to non-volatile compounds such as the chlorophenoxy acids herbicides.

Enrichment and clean-up procedures are nearly always necessary in connection with the HPLC analysis of the chlorophenoxy acids in surface water, urine, soil or sediment. Liquid-Liquid extraction $[9,29,30]$, solid-phase extraction $[11,22,25,31-34]$ and enrichment on a precolumn $[33,25,35-37]$ or a supported liquid membrane [38-40] can be utilized as the sample pretreatment procedure. Recently, a sample pretreatment technique using isotachophoresis as the sample clean-up and enrichment step prior to the LC analysis was developed [41]. Promising results were obtained by this method.

Capillary zone electrophoresis (CZE) and micellar electrokinetic capillary chromatography (MECC) also seem to be attractive techniques for the analysis of the chlorophenoxy acids. Due to their outstanding separation efficiency, high speed and potential for automation, CZE and MECC have already been used to separate a large variety of compounds. Very often $U V$ detection is applied in capillary electrophoresis (CE). Unfortunately this detection technique has a somewhat limited sensitivity (in the range of $10^{-5} \mathrm{M}$ ). However, indirect fluorescence detection and laser-induced fluorescence detection can also be used with $\mathrm{CE}$. These techniques can enhance the sensitivity to the range of $10^{-7}-10^{-9} \mathrm{M}[42,43]$. Applications include amino acids $[42,44]$, peptides $[45,46]$, proteins [47, 48], priority pollutants [49], vitamins [50-52] and drugs [53-55].

In many types of samples herbicides are expected to occur in concentrations less than $0.1 \mathrm{ppb}$. This is far below the detection limit of the UV-detection systems commonly applied. In this part of our research we did not give any consideration to this detection problem. Much higher concentrations of the herbicides than normally occur in, for example, water samples were used for the method development procedures.

In this study, a method for the separation of a number of chlorophenoxy acid herbicides by MECC was developed with attention being focussed on the separation efficiency and tuning of the selectivity. The effects of some surfactants and methanol, in various concentrations added to 
the buffer, on the separation of these herbicides were investigated. The herbicides (concentration about 200 ppm for each component) were detected by a multiwavelength UV detector. Processing of the detector signals allowed three-dimensional plots of the data, peak confirmation and peak purity evaluation via comparison of spectra.

\section{Theory}

In MECC, both neutral and charged compounds can be separated according to their differences in hydrophobicities and electrophoretic mobilities [56-59].

When a neutral compound is solubilized by the micellar phase the capacity factor, $\mathrm{k}$, can be expressed as:

$$
\mathrm{k}=\frac{\mathrm{t}_{\mathrm{R}}-\mathrm{t}_{0}}{\mathrm{t}_{0} \cdot\left(1-\frac{\mathrm{t}_{\mathrm{R}}}{\mathrm{t}_{\mathrm{mc}}}\right)}
$$

where: $t_{R}$ : the migration time of a neutral solute,

$t_{0}$ : the migration time of an unretained solute,

$t_{m c}$ : the migration time of a neutral solute completely retained in the micelle.

From this a general expression for the solute velocity in MECC can be given:

$$
v_{\mathrm{s}}=\frac{\mathrm{k}}{1+\mathrm{k}} \cdot v_{\mathrm{mc}}+\frac{\mathrm{k}}{1+\mathrm{k}} \cdot v_{\mathrm{eo}}
$$

where $v_{s}$ : the velocity of the solute,

$v_{\mathrm{eo}}$ : the velocity of an unretained solute,

$v_{\text {mec }}:$ the velocity of the micelle.

In the case where charged solutes arc also present in the sample and assuming that the electrophoretic velocity of the micelles remains constant, the velocities of such charged solutes are given by:

$$
v_{s}(i)=\frac{k_{i}}{1+k_{i}} \cdot v_{m c}+\frac{1}{1+k_{i}} \cdot v_{e o}+\frac{1}{1+k_{i}} \cdot v_{e p} \text { (i) (3) }
$$

where $v_{s}$ (i): the velocity of the charged solute,

$v_{e p}(i)$ : the electrophoretic velocity of the charged solute in the aqueous phase,

$\mathrm{k}_{\mathrm{i}}$ : the capacity factor of the charged solute.

These equations clearly show that the nature of the applied surfactants, the composition of the buffers and the physico-chemical properties of the column are major parameters which influence a MECC separation.

\section{Experimental}

\section{Chemicals}

2-(2,4-dichlorophenoxy)-propionic acid (2,4-DP), 4-(2,4dichlorophenoxy) butyric acid (2,4-DB), 4-chloro-2-methylphenoxy acetic acid (MCPA), 2-(4-chloro-2-methylphe- noxy) propionic acid (MCPP), 4-(4-chloro-2-methylphenoxy) butyric acid (MCPB), 2, 4, 5-trichlorophenoxy acetic acid (2,4,5-TPA), 2-(2,4,5-trichlorophenoxy)-propionic acid (2,4,5-TPP), 3,6-dichloro-2-methoxy benzoic acid (Dicamba), 2,3,6-trichlorobenzoic acid (2,3,6-TB) and 3-isopropyl-2,1,3-benzothiadiazin-4-on-2,2-dioxide (bentazon) were purchased from Schmidt (Amsterdam The Netherlands).

Sodium dodecylsulphate (SDS) and cetyltrimethylammonium bromide (CTAB) were obtained from Aldrich Chemical Co. (Milwaukee, WI, USA). All the other reagents and solvents were purchased from Merck (Merck AG, Darmstadt, FRG). HPLC grade water, prepared by filtering deionized water through a Milli-Q Water purification system (Millipore Corp., Bedford, USA) was used for the preparation of the buffer solutions and samples.

The buffer solutions and a standard mixture of the herbicides (about $0.2 \mathrm{mg} / \mathrm{ml}$ for each compound) were prepared by dissolving appropriate amounts of the reagents in the deionized water. Both the buffers and the samples were filtered through $0.45 \mu \mathrm{m}$ Millex-GS filters (millipore) prior to use.

\section{Equipment and Procedures}

The experiments were carried out on a spectra Physics $1000^{\mathrm{TM}}$ capillary electrophoresis system equipped with a multi-wavelength scanning UV detector (Spectra-Physics Inc., San Jose, CA, USA).

Automated capillary rinsing, sample introduction and execution of the electrophoretic runs were controlled by an IBM personal system/2 computer (Model 70386 ) with software version 1.3. Multi-wavelength spectral data were collected, stored and processed on the same computer. The high speed polychrome mode by scanning from 200 $\mathrm{nm}$ to $300 \mathrm{~nm}$ at $5 \mathrm{~nm}$ intervals was employed in these experiments. This permitted three dimensional plotting of the electrochromatograms, peak confirmation and peak purity evaluation via the comparison of absorption spectra. Sample introduction on this equipment could be performed either by electromigration or the vacuum technique. In this work vacuum injection was applied throughout the experiments to avoid sample discrimination. This was effected by applying the preset vacuum at the cathode side for a period of $1 \mathrm{sec}$ (typically about $2 \mathrm{nl}$ for a $50 \mu \mathrm{m}$ i.d. column).

Fused silica capillary columns with $50 \mu \mathrm{m}$ i.d., total length $44 \mathrm{~cm}$, effective separation length $37 \mathrm{~cm}$ (Siemens, Germany) were used for all the experiments. Prior to use new capillary columns were rinsed with $0.1 \mathrm{~N}$ sodium hydroxide solution for $20 \mathrm{~min}$ and subsequently by water and the buffer solutions to be used in the experiments, for $60 \mathrm{~min}$ and $20 \mathrm{~min}$, respectively. Thereafter the procedure for each experiment consisted of rinsing the capillary with water for $5 \mathrm{~min}$ and with the buffers for $10 \mathrm{~min}$. In all the experiments a constant voltage of $15 \mathrm{kV}$ was applied and the temperature of the separation system was kept al $25^{\circ} \mathrm{C}$. 


\section{Results and Discussion}

\section{The Effect of Surfactants on the Separations}

From the chemical structures of the herbicides under study, shown in Table 1 , and some preliminary experiments it was concluded that three paris of components in the mixture would be difficult to separate. They will be referred to in this paper as:

pair a (consisting of compound 8 and 10 );

pair $b$ (consisting of compound 1 and 2 );

pair $c$ (consisting of compound 6 and 7).

At the $\mathrm{pH}$ values of the buffers selected for use in this study, all compounds are partially or totally dissociated. Therefore, they carry negative charge and their migration is governed by the electroosmotic flow, the electrophoretic mobility and eventually by their interaction with the micellar phase in those cases where MECC is applied. very high efficiencies (average plate numbers about 120,000 for each compound) were obtained throughout satisfactiments. Even so it was hardly possible to achieve tions onctory separations by using phosphate buffer soluof the because of the very similar chemical structures based target compounds. For this reason a separation ased on MECC was developed.

The solubilization of the compounds by specific micelles may contribute to the migration behaviour and thus to a selective separation. The results obtained at different SDS concentrations on the separation of the three pairs of the components are presented in Figure 1. The resolution Within the three paris increases with the concentration of SDS. This is due to the increased hydrophobicity of components 8,1 and 6 in pairs $a, b$ and $c$ respectively (Table I). So an increased interaction of these compounds corresponding to the concentrations of the micelles could

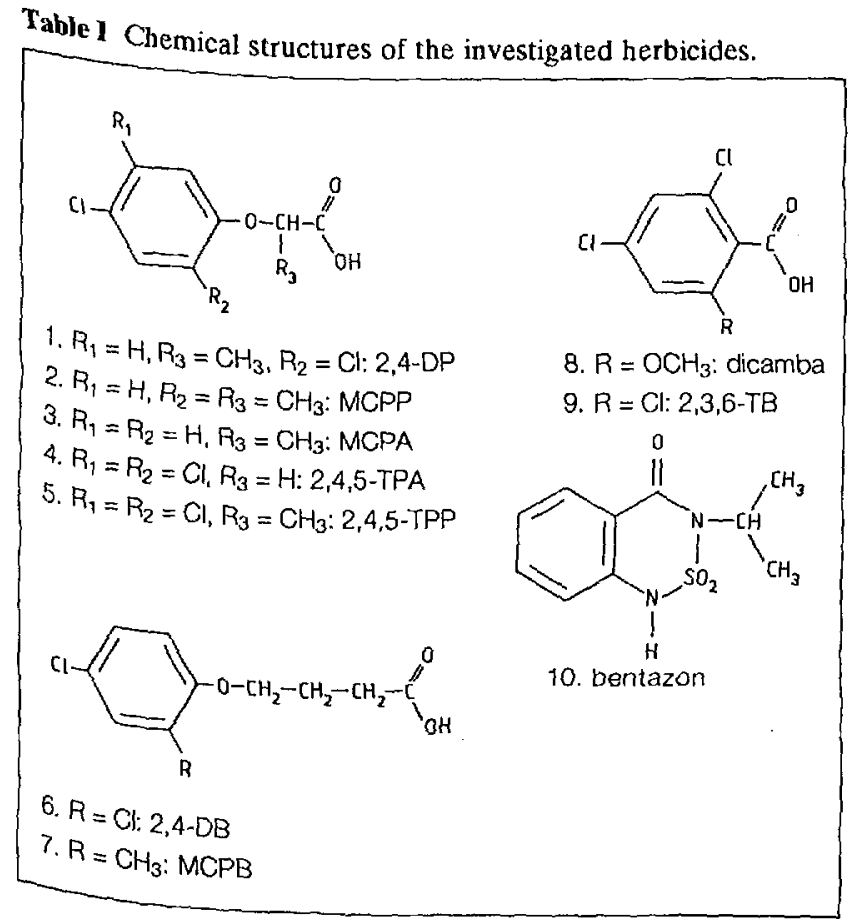

be expected. A typical three-dimensional electrochromatogram of the 10 herbicides under study is presented in Figure 2.

At a concentration of $0.1 \mathrm{M} \mathrm{SDS}$, the resolution of 2,4-DB and MCPB approaches unity. However, the two peaks are asymmetric. A further increase in the SDS concentration will increase the electrical current to intolerable values. This will cause additional peak broadening due to the temperature gradient inside the column.

It has been shown that the addition of Brij 35 (a non-ionic surfactant) to an anionic surfactant system may improve the resolution in MECC [60]. A distinct advantage of using Brij 35 is that a high concentration of Brij 35 can be used without influencing the current in the electrophoretic system. Therefore, Brij 35 was employed in this

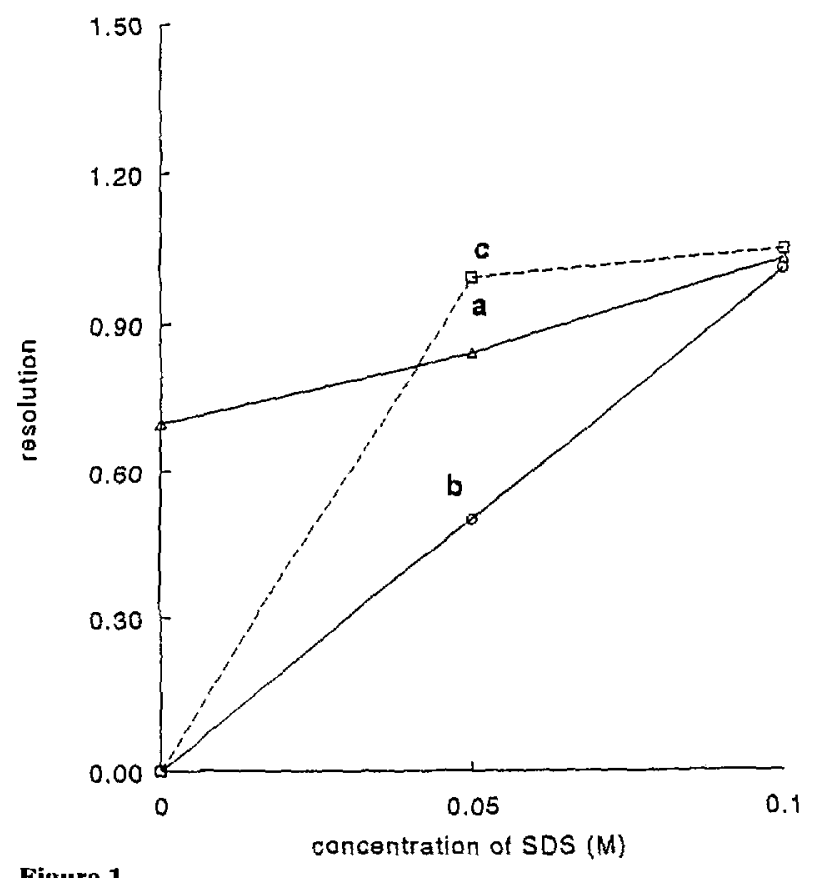

Figure 1

Plot of the resolution versus the concentration of SDS. The experiments were conducted with a voltage of $15 \mathrm{kV}$ across $44 \mathrm{~cm} \times$ $50 \mu \mathrm{m}$ i.d. column, effective length $37 \mathrm{~cm}$, buffer: $0.02 \mathrm{M}$ aqueous phosphate solution. $\mathrm{T}=25^{\circ} \mathrm{C}$. (a) bentazon and dicamba; (b) MCPP and 2,4-DP; (c) MCPB and 2,4-DB.

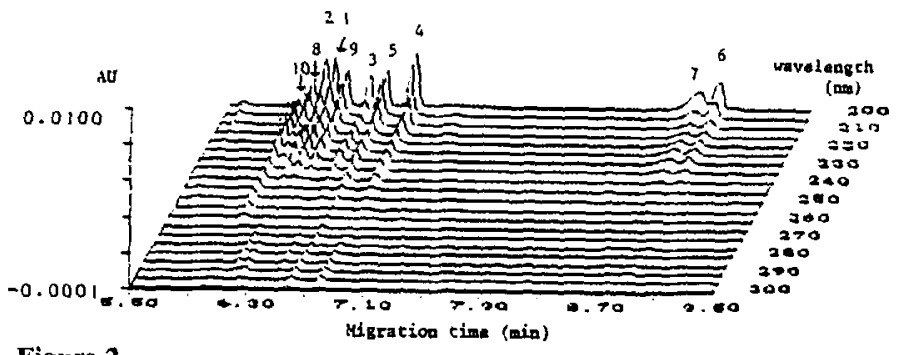

Figure 2

Three dimensional electrochromatograms of a standard mixture of ten chlorophenoxy acids in $0.1 \mathrm{M}$ SDS and $0.02 \mathrm{M}$ phosphate buffer solution. The experiments were conducted with a voltage of $15 \mathrm{kV}$ across $44 \mathrm{~cm} \times 50 \mu \mathrm{m}$ i.d. column, effective length $37 \mathrm{~cm}$, buffer: 0.05 $\mathrm{M}$ SDS and $0.02 \mathrm{M}$ aqueous phosphate solution. $\mathrm{T}=25^{\circ} \mathrm{C}$. Peak numbers see Table I. 


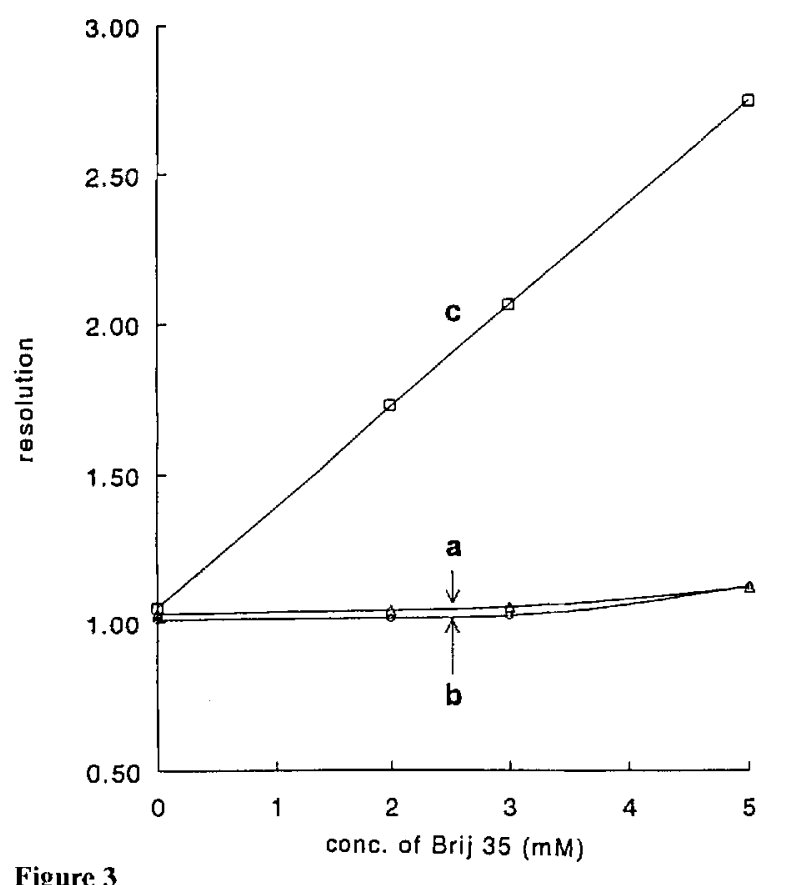

Figure 3

Plot of the resolution versus the concentration of Brij 35. The experiments were conducted with a voltage of $15 \mathrm{kV}$ across $44 \mathrm{~cm} \times$ $50 \mu \mathrm{m}$ i.d. column, cffective length $37 \mathrm{~cm}$, buffer: $0.05 \mathrm{M}$ SDS and $0.02 \mathrm{M}$ aqueous phosphate solution. $\mathrm{T}=25^{\circ} \mathrm{C}$. (a) bentazon and dicamba; (b) MCPP and 2,4-DB.

investigation, in combination with SDS, to study its effect on the separation of the chlorinated phenoxy acids. The results obtained with various concentration of Brij 35 is shown in Figure 3. A slightly increased resolution for pairs $a$ and $b$ was observed at increasing concentrations of Brij 35. This indicates that the interaction between these solutes and Brij 35 is less effective. The resolution of pair c, however, was almost proportionally increased with the concentration of Brij 35. Compared with the other compounds, 2,4-DB and MCPB have relatively long molecular chains and Brij 35 is a linear moleculer. This may result in stronger interaction between these two solutes and Brij 35 .

Further improvement in the resolution of the three pairs of the solutes can be obtained by increasing the concentration of Brij 35. However, the migration times also change resulting in overlapping of compounds 3 and 5 and a reduction in the overall separation performance.

Cetyltrimethylammonium (CTAB) has been shown to be effective for the separation of a number of negatively charged compounds [61]. It was also applied in this work in order to evaluate its effect on the separation of the chlorophenoxy acids. The application of CTAB did not result in a sufficient separation of the chlorophenoxy acids. The target compounds are very alike and there interaction with CTAB is probably, very similar.

To achieve a satisfactory separation of the target compounds a compromise has to be made in the composition of the buffer. The best overall separation of the herbicides under study was achieved by the application of $0.02 \mathrm{M}$ phosphate buffer solution containing $0.1 \mathrm{M}$ SDS and 3 . $10^{-3} \mathrm{M}$ Brij 35 (Figure 4).

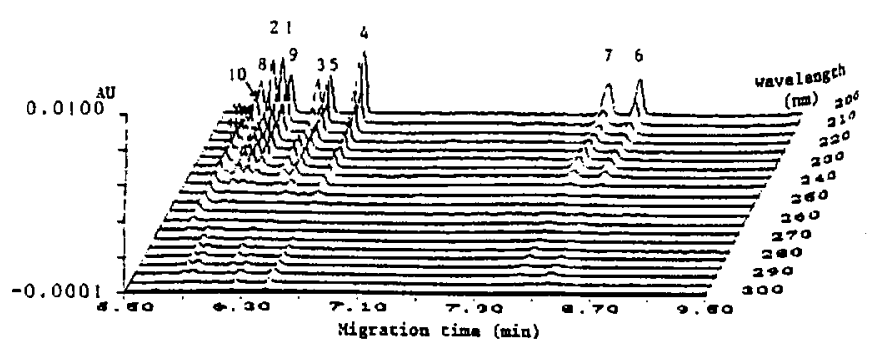

Figure 4

Three dimensional clectrochromatograms of a standard mixture of ten chlorophenoxy acids. All experiments were carried out with voltage of $15 \mathrm{kV}$ across $44 \mathrm{~cm} \times 50 \mu \mathrm{m}$ i.d. column, effective length 37 $\mathrm{cm}$, buffer: $0.1 \mathrm{M}$ SDS and $3 \times 10^{-3} \mathrm{M}$ Brij 35 in $0.02 \mathrm{M}$ aqueout phosphate solution. $\mathrm{T}=25^{\circ} \mathrm{C}$. Peak numbers see Table $\mathrm{I}$.

\section{The Influence of Methanol on the Separation}

It has been shown that a small percentage of organic modifier may also improve the separation efficiency in MECC $[62,63]$. The resolution of the three pairs of solutes with addition of various portions of methanol to the buffer are depicted in Figure 5.

An improvement in resolution of the pairs $a$ and $b$ was observed with increasing amounts of methanol. A temarkable enhancement in the resolution of the pair $c$ was achieved by increasing the methanol percentages.

This improvement in resolution can be explained by the increase in the elution range as a result of the addition of the modifiers [62]. In fact, a smaller value of $t_{0} / t_{m c}$ is obtained by the addition of methanol. It is evident that resolution increases with decreasing values of $t_{0} / t_{\mathrm{mc}}$ [59]. Consequently, increased resolutions can be expected in the case of decreasing values of $\mathrm{t}_{0} / \mathrm{t}_{\mathrm{mc}}$

The migration times of the other four components $(3,4,5$ and 9 in Table I) were also influenced by the addition of methanol to the buffer solution. Again, as with the addition of Brij 35, an increase in migration time is observed for these compounds. This has a negative effect on the overall separation of the sample, e.g. compound 3 starts to overlap compound 5 (Figure 6).

With respect to the qualitative and quantitative analysis, multiwavelength detection allowed three-dimensional plotting of the electrochromatograms (Figures 2 and 4) showing the relationships of absorbance vs. migration times vs. wavelength. The absorption spectrum of each component can be extracted from the collected data points indicated as time slices (Figure 7 ). This provides additional possibilities for the identification of a compound.

Figure 7 shows that unlike the spectra of pair a, the spectra of paris $b$ and $c$ of the chlorophenoxy acids are quite similar. This indicates that a sufficient separation of these chlorophenoxy acids is mandatory to achieve reliable quantitative and qualitative analysis results.

As an example the results of migration times and peak areas for six compounds are presented in Table II. 

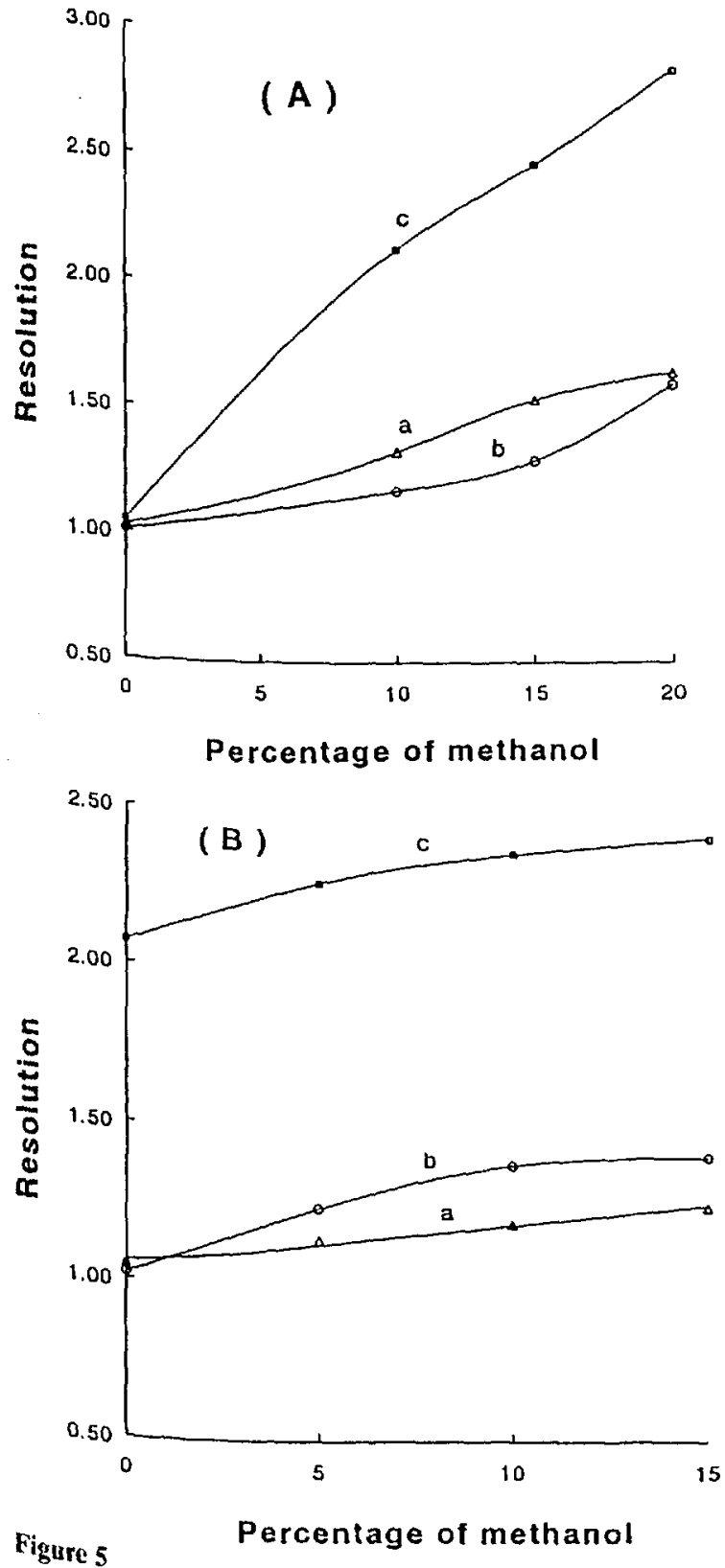

Figure 5

Plot of resolution versus methanol percentage. (A) $0.02 \mathrm{M}$ phosphate buffer with $0.1 \mathrm{M} \mathrm{SDS}$; (B) $0.02 \mathrm{M}$ aqueous phosphate buffer cond $0.1 \mathrm{M} \mathrm{SDS}$ and $3 \times 10^{-3} \mathrm{M}$ Brij 35. All experiments were conducted with a voltage or $15 \mathrm{kV}$ across $44 \mathrm{~cm} \times 50 \mu \mathrm{m}$ i.d. column MCPP length $37 \mathrm{~cm}$. $\mathrm{T}=25^{\circ} \mathrm{C}$. (a) bentazon and dicamba; (b) $\mathrm{MCPP}$ and $2,4-\mathrm{DP}$; (c) MCPB and 2,4-DB

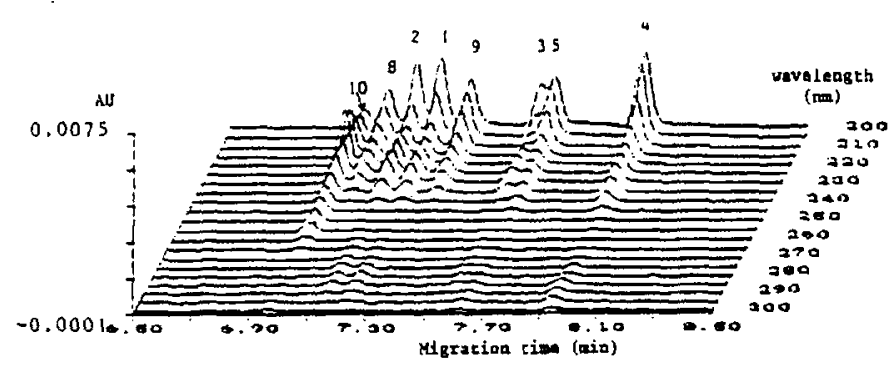

Figure 6

Three dimensional electrochromatograms of a standard mixture of ten chlorophenoxy acids. The experiments were carried out with a voltage of $15 \mathrm{kV}$ across $44 \mathrm{~cm} \times 50 \mu \mathrm{m}$ i.d. column, effective length 37 $\mathrm{cm}$, buffer: $0.1 \mathrm{M}$ SDS and $3 \times 10^{-3} \mathrm{M}$ Brij 35 and $10 \%$ methanol in $0.02 \mathrm{M}$ aqueous phosphate solution. $\mathrm{T}=25^{\circ} \mathrm{C}$. Peak numbers see Table I.
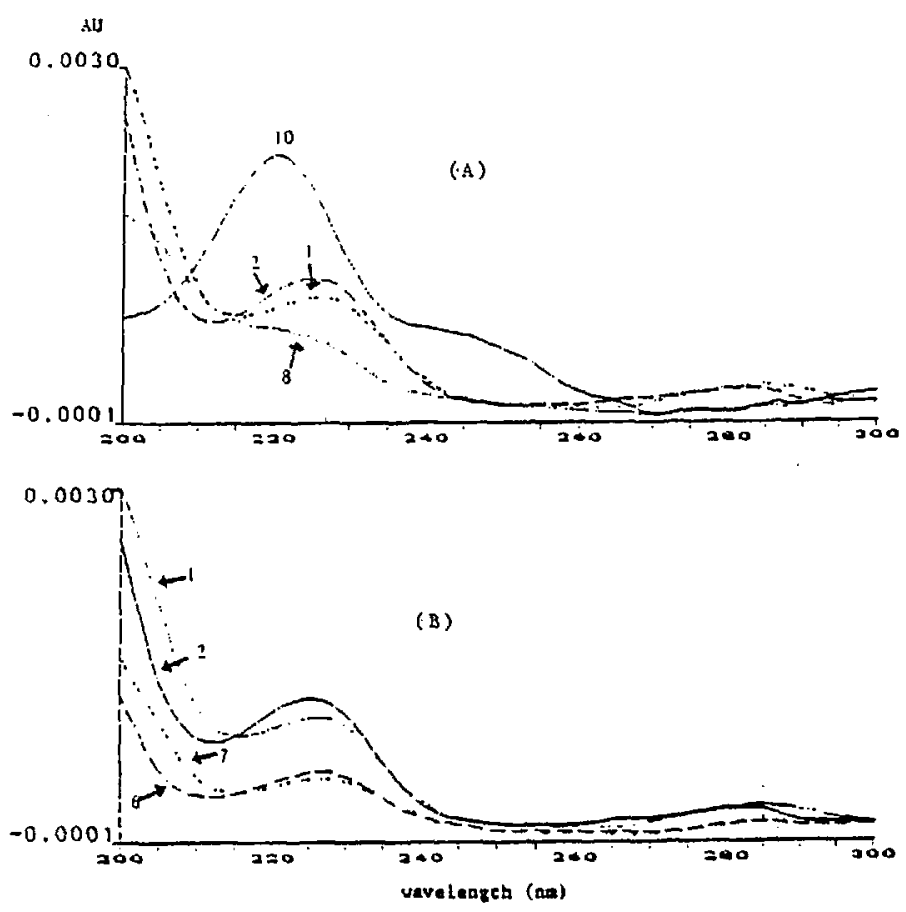

Figure 7

Absorption spectra obtained as a time slice from the data in Figure 4. (A) Pairs a and $b$; (B) pairs b and $c$.

Table II Repeatability of migration times and peak areas.

\begin{tabular}{|cccccccc|}
\hline & \multicolumn{3}{c}{ Migration times } & & \multicolumn{3}{c|}{ Peak areas } \\
\cline { 2 - 3 } \cline { 7 - 8 } Peak No. & $\mathrm{s}$ & $\sigma$ & $\sigma / \mathrm{s}(\%)$ & & $\mathrm{s}$ & $\sigma$ & $\sigma / \mathrm{s}(\%)$ \\
\hline 10 & 5.67 & 0.05 & 0.9 & 3613 & 44 & 1.2 \\
8 & 5.72 & 0.05 & 0.9 & & 8232 & 199 & 2.4 \\
2 & 5.81 & 0.05 & 0.9 & & 13470 & 193 & 1.4 \\
1 & 5.87 & 0.06 & 1.0 & & 14217 & 311 & 2.2 \\
7 & 8.11 & 0.09 & 1.1 & 14772 & 209 & 1.4 \\
6 & 8.32 & 0.11 & 1.4 & 14148 & 247 & 1.7 \\
\hline
\end{tabular}

Conditions: $0.02 \mathrm{M}$ aqueous phosphate buffer containing $0.1 \mathrm{M}$ SDS and $3 \times 10^{-3} \mathrm{M}$ Brij 35 . Sample concentration about $0.2 \mathrm{mg} / \mathrm{ml}$ for each compound, constant voltage $15 \mathrm{kV}$, column: $44 \mathrm{~cm} \times 50 \mu \mathrm{m}$ i.d. column and effective length $37 \mathrm{~cm} . T=25^{\circ} \mathrm{C}$. Peak numbers see Table I. Number of experiments $\mathrm{n}=3$, saverage value, $\sigma$-standard deviation, $\sigma / \mathrm{s}(\%)$-relative standard deviation. 


\section{Conclusions}

The selectivity of the MECC technique is demonstrated in this study for compounds which have similar chemical structures. Tuned selectivity in the separation was obtained by optimizing parameters such as the concentration of SDS and Brij 35 and the percentage of methanol in the buffers.

SDS combined with Brij 35 as the micellar agent provided satisfactory separations and relatively short analysis time. Also, high efficiencies (more than 100,000 theoretical plates) were obtained for the separation of these chlorinated phenoxy acid herbicides under MECC conditions.

Relative standard deviations of the migration times are about $1 \%$ and the repeatabilities for peak areas are about $2 \%$ for all the herbicides investigated.

The multi-wavelength detection provided useful additional information. The characterization of the sample zones by their migration times and adsorption spectra proved to be a powerful tool for solute identification.

The MECC technique offers great selectivity and flexibility. Further investigations of the applicability of this technique in other areas should produce valuable analytical procedures.

\section{References}

[1] R. W. Bovey, A. Young, The Science of 2,4,5-T and Associated Phenoxy Herbicides, Wiley, New York, 1980, p. 301.

[2] N. Gorde, M. Beroza, Anal. Chem. 24, 1968 (1952).

[3] S. Gottlieb, P. B. Marsh, Ind. Eng. Chem. 18, 16 (1946).

[4] A. Lechien, P. Valenta, H. W. Nürnberg, C. J. Patriache, Fresenius Z. Anal. Chem. 306, 156 (1981).

[5] W. H. Gulerman, D. J. Lisk, J. Agric. Food Chem. 11, 301 (1963).

[6] S. F. Howard, G. Yip, J, Assoc. Off. Anal. Chem. 54, 970 (1971).

[7] S. U. Khan, J. Assoc. Off. Anal. Chem. 58, 1027 (1975).

[8] A. S. Y. Chau, K. Terry, J. Assoc. Off. Anal. Chem. 59, 633 (1976).

[9] H. Agemian, A. S. Y. Chau, J. Assoc. Off. Anal. Chem. 60, 1070 (1977).

[10] R. Bailey, G. LeBel, J. F. Lawrence, J. Chromatogr. 161, 251 (1978).

[11] J. J. Richards, J. S. Fritz, J. Chromatogr. Sci. 18, 35 (1980).

[12] M. L. Hopper, J. Agric. Food Chem. 35, 265 (1982).

[13] H. Roseboom, H. A. Herbold, C.J. Berkoff, J. Chromatogr. 249, 323 (1982).

[14] E. G. Cotterill, Analyst (London), 107, 76 (1982).

[15] F. I. Dauska, J. High Resolut. Chromatogr. \& Chromatogr. Commun. 7, 660 (1984).

[16] B. Blessington, N. Crabb, S. Karkee, A. Northage, J. Chromatogr. 469,183 (1989).

[17] T. Tsukioka, T. Murakami, J. Chromatogr. 469, 351 (1989).

[18] E. De Felip, A. Di Domenico, F. Volpi, J. Chromatogr. 489, 404 (1989).

[19] F. Eisenbeiss, H. Sieper, J. Chromatogr. 83, 439 (1973).

[20] J. F. Lawrence, D. Turton, J. Chromatogr. 159, 207 (1978).

[21] P. Cabras, P. Diana, M. Meloui, F. M. Pirisi, J. Chromatogr. 234, 249 (1982).

[22] P. Jandera, L. Suoboda, J. Kubát, J. Schvantner, J. Churácek, J. Chromatogr. 292, 71 (1984).

[23] J. A. Apffel, U. A. Th. Brinkman, R. W. Frei, J. Chromatogr. 312, 153 (1984).
[24] R. D. Voyksner, J. T. Bursey, E. D. Pellizari, J. Chromatogr. 312, 221 (1984).

[25] M. Akerblom, J. Chromatogr. 319, 427 (1985).

[26] S. H. Hoke, E. E. Brueggeman, L. J. Baxter, T. Trybus, J. Chromatogr. 357, 429 (1986).

[27] B. Blessington, N. Crabb, J. Chromatogr. 454, 450 (1988).

[28] B. Blessington, N. Crabb, J. Chromatogr. 483, 349 (1989).

[29] N. P. Hill, A. E. MacIntyre, R. Perry, J. N. Lester, Intern. J. Environ. Anal. Chem. 15, 107 (1983)

[30] V. Lopez-Avila, P. Hirata, S. Kraska, J. H. Taylor, Jr., J. Agric Food Chem. 34, 530 (1986).

[31] S. Mierzwa, S. Wirek, J. Chromatogr. 136, 105 (1977).

[32] J. J. Richards, C. D. Chriswell, J. S. Fritz, J. Chromalogr. 199, $143(1980)$.

[33] R. L. Smith, D. I. Pietrzyk, J. Chromatogr. Sci. 21, 282 (1983).

[34] M. J. Bertrand, A. W. Ahmed, B. Sarrasin, V. N. Mallet, Anal Chem. 59, 1302 (1987).

[35] R. B. Geerdink, J. Chromatogr. 445, 273 (1988).

[36] R. B. Geerdink, C. A. A. van Balkom, H. J. Brouwer, J. Chromatogr. 481, 275 (1989).

[37] R. B. Geerdink, A. M. V. C. Graumans, J. Viveen, J. Chromato gr. 547, 478 (1991).

[38] G. Audunsson, Anal. Chem. 58, 2714 (1986).

[39] G. Audunsson, Anal. Chem. 60,1340 (1988).

[40] G. Nilvé, G. Audunsson, J. Jönsson, J. Chromatogr. 471, 151 (1989).

[41] P.J.M. Hendriks, H. A. Claessens, Th. M. Noij, F. M. Everaerts, 15th International Symposium on Column Liquid Chromatog raphy, Switzerland, June 3-7, 1991, p. 95/1.

[42] W. G. Kuhr, E. S. Yeung, Anal. Chem. 60, 1832 (1988).

[43] T. Lee, E. S. Yeung, J. Chromatogr. 565, 197 (1991).

[44] K. Otsuka, S. Terabe, T. Ando, J. Chromatogr. 332, 219 (1985).

[4S] P. D. Grossman, J. C. Colburn, H. H. Lauer, R. G. Nielson, R M. Riggin, G. S. Sittampalam, E. C. Rickard, Anal. Chem. 61. $1186(1989)$.

[46] B. L. Karger, A. S. Cohen, A. Guttman, J. Chromatogr. 492, 585 (1989).

[47] G. J. M. Bruin, J. P. Chang, R. H. Kuhlman, K. Zegers, J. C. Kraak, H. Poppe, J. Chromatogr. 471, 429 (1989).

[48] K. A. Cobb, B. Dolnik, M. Novotny, Anal. Chem. 62, 2487 (1990).

[49] C. P. Ong, C. L. Ng, N. C. Chong, H. K. Lee, S. F. Y. Li, J. Chromatogr. 516, 263 (1990).

[50] S. Fujiwara, S. Iwasa, S. Honda, J. Chromatogr, 497, 133 (1988).

[S1] H. Nishi, N. Tsumagari, T. Kakimoto, S. Terabe, J. Chromatogi. 465, 331 (1989).

[52] C. P. Ong, C. L. Ng, H. B. Lee, S. F. Y. Li, J. Chromatogr. 547, 419 (1991).

[53] H. Nishi, S. Terabe, Electrophoresis 11, 691 (1990).

[54] W. Thormann, P. Meier, C. Marcolli, F. Binder, J. Chromatogr. 545, 445 (1991).

[55] P. G. Pietta, P. L. Mauri, A. Rava, G. Sabbatini, J. Chromatogr 549, 367 (1991).

[56] S. Terabe, K. Otsuka, K. Ichikawa, A. Tsuchiya, T. Ando, Anal Chem. 56, 111 (1984).

[57] S. Terabe, K. Oisuka, T. Ando, Anal. Chem. 57, 834 (1985).

[58] R. J. Hunter, "Zeta Potential in Colloid Science". Academic Press, London, 1981.

[59] J. P. Foley, Anal. Chem. 62, 1302 (1990).

[60] H. T. Rasmussen, L. K. Goebel, H. M. McNair, J. Chromatogr 517, 549 (1990).

[61] H. Nishi, N. Tsumagari, S. Terabe, Anal. Chem. 61, 2434 (1989)

[62] A. T. Balchunas, M.J. Sepaniak, Anal. Chem. 59, 1466 (1987).

[63] J. Gorse, A. T. Balchunas, D. F. Swaile, M. J. Sepaniak, J. High Resolut. Chromatogr. \& Chromatogr. Commun. 11, 554 (1988)

Received: Feb. 6, 1992 Revised manuscript received: April 1, 1992 Accepted: April 7, 1992 